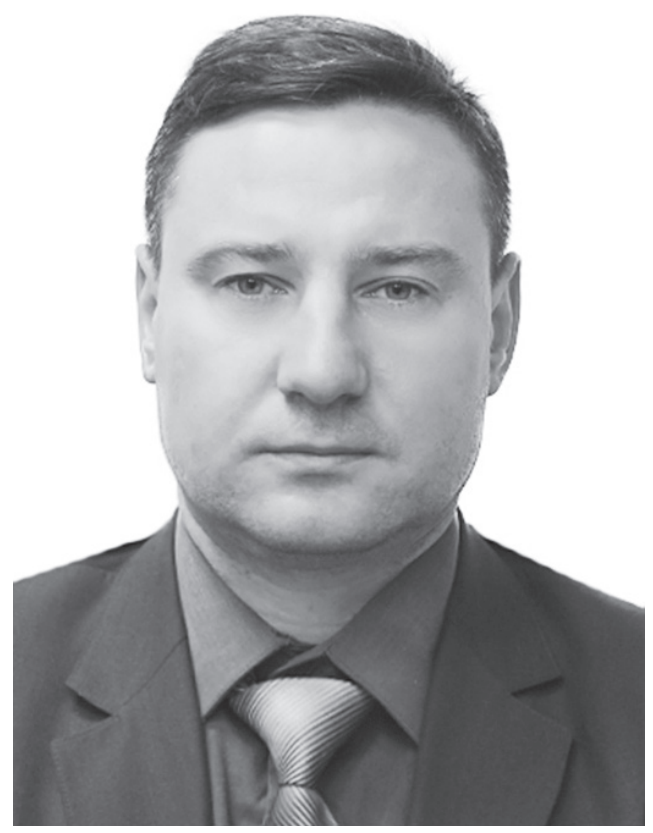

Гребенюк Максим Васильевич, кандидат юридических наук, дочент, заслуженный юрист Украины, руководитель Межведомственного научно-исследовательского иентра по проблемам борьбы с организованной преступностью при СНБО Украины, 03035, г. Киев, Соломенская площадь, 1, тел.: (067) 44431 03, e-mail:max-felix@ukr.net

ORCID: 0000-0003-1249-5576
UDC: 351.865

2224-2019-4(19)-78-91

Hrebeniuk Maksym Vasilievich, Head of the Interagency scientific and research Centre on problems of combating organized crime under National Security and Defense Council of Ukraine, PhD in Lare, Associate Professor, Honored lazoyer of Ukraine, 03035, Kyiv, Solomenska Ploshcha, 1, tel.: (067) 44431 03,e-mail:max-felix@ukr.net

ORCID: 0000-0003-1249-5576

\section{Гребенюк Максим Васильович,} кандидат юридичних наук, доцент, заслужений юрист Украӥни, керівник Міжвідомчого науково-дослідного центру з проблем боротьби з організованою злочинністю при РНБО України, 03035, м. Київ, Солом'янська площа,1, тел.: (067) 44431 03,e-mail:max-felix@ukr.net

ORCID: 0000-0003-1249-5576
DOI: https://doi.org/10.32689/2617-

\title{
THE DIRECTIONS OF IMPROVING THE LEGISLATIVE FRAMEWORK IN THE SPHERE OF SUPPLY STATE SECURITY IN THE VECTOR - FIGHT AGAINST ORGANIZED CRIME
}

Abstract. The problematic issues of the implementation of the state policy of Ukraine in the fight against organized crime as a strategic vector to ensure state security are considered. A review of legislative initiatives and practical measures taken to build public policy concepts in the fight against organized crime in the context of law enforcement reform was carried out. The content and directions of the strategy of combating organized crime as a fundamental document, which is devoted to the problems of ensuring an effective fight against organized crime through the introduction of international standards and the formation of an adequate system of measures to prevent and combat the activities of organized 
criminal groups, including transnational relations, are defined. The principles of state security policy which are carried out in order to form an effective system of institutional support for the fight against organized crime are analyzed. The perspective directions of strengthening the capabilities of law enforcement agencies - subjects of the fight against organized crime are detailed, which include: practical implementation in their activities of the system of criminal analysis and risk analysis of organized crime, which comply with the EU standard, in particular the methodology for assessing the threat of organized crime and serious crimes (SOCTA Ukraine); establishing effective cooperation with Interpol, Europol and other international partners on a bilateral and multilateral basis in accordance with national legislation and ratified international treaties. The ways of increasing the effectiveness of law enforcement activities in the fight against organized crime in the context of ensuring the state security of Ukraine, mechanisms for establishing strategic communications in the fight against organized crime are generalized.

The need to strengthen the management of the Government of Ukraine in developing and approving a Plan of measures to implement the strategy against organized crime, and the need to prepare recommendations based on the analysis of the implemented concepts of state policy in the fight against organized crime are emphasized. The feasibility of assessing the state of implementation of the strategy against organized crime using the appropriate criteria based on the best law enforcement practices of the European experience has been determined. The feasibility of assessing the state of implementation of the strategy against organized crime using the appropriate criteria based on the best law enforcement practices of the European experience has been determined. The necessity of publishing at the national level an annual report on the implementation of state policy in the fight against organized crime has been substantiated. The priorities of modern law enforcement activities and the ways of improving the legislative measures in the sphere of state security in the fight against organized crime have been identified.

Keywords: state policy in the fight against organized crime, public administration, protection of state security, law enforcement reform, law enforcement activities, organized crime, criminal risk analysis, principles of state security policy.

\section{ШЛЯХИ УДОСКОНАЛЕННЯ ЗАКОНОДАВЧОГО ЗАБЕЗПЕЧЕННЯ ЗАХОДІВ У СФЕРІ ЗАХИСТУ ДЕРЖАВНОЇ БЕЗПЕКИ ЗА ВЕКТОРОМ - БОРОТЬБА 3 ОРГАНІЗОВАНОЮ ЗЛОЧИННІСТЮ}

Анотація. Розглянуто проблемні питання реалізації державної політики України у сфері боротьби з організованою злочинністю як стратегічного вектора забезпечення державної безпеки. Здійснено огляд законодавчих ініціатив та практичних заходів, які вживаються з метою побудови концептів державної політики у сфері боротьби з організованою злочинністю в умовах реформування правоохоронних органів. Визначено зміст та напрями стратегії боротьби з організованою злочинністю як фундаментального документа, 
який присвячений запровадженню міжнародних стандартів та формуванню адекватної системи заходів щодо запобігання та боротьби з діяльністю організованих злочинних угруповань, у тому числі й транснаціональними зв'язками. Проаналізовано засади державної безпекової політики, які здійснюються з метою формування ефективної системи інституційного забезпечення боротьби з організованою злочинністю. Деталізовано перспективні напрями посилення спроможностей правоохоронних органів - суб'єктів боротьби 3 організованою злочинністю, до яких належать: практичне запровадження в їх діяльність системи кримінального аналізу та аналізу ризиків організованої злочинності, сумісної зі стандартами СС, зокрема методології оцінки загроз організованої злочинності та тяжких злочинів (SOCTA Україна); налагодження співробітництва з Інтерполом, Європолом та іншими міжнародними партнерами на двосторонній і багатосторонній основі відповідно до національного законодавства та ратифікованих міжнародних договорів. Узагальнено шляхи підвищення ефективності правоохоронної діяльності у сфері боротьби з організованою злочинністю в контексті забезпечення державної безпеки України, механізми налагодження стратегічних комунікацій у сфері боротьби з організованою злочинністю.

Акцентовано увагу на необхідності посилення управлінської діяльності Уряду України щодо розробки та затвердження плану заходів на виконання стратегії боротьби з організованою злочинністю, підготовки рекомендацій за результатами аналізу впроваджених концептів державної політики у сфері боротьби з організованою злочинністю. Визначено доцільність проведення оцінки стану виконання стратегії боротьби з організованою злочинністю 3 використанням відповідних критеріїв, виходячи з кращих правоохоронних практик європейського досвіду. Обгрунтовано необхідність оприлюднення на національному рівні щорічного звіту з реалізації державної політики у сфері боротьби з організованою злочинністю. Визначено пріоритетні завдання сучасної правоохоронної діяльності та шляхи удосконалення законодавчого забезпечення у сфері захисту державної безпеки.

Ключові слова: державна політика у сфері боротьби з організованою злочинністю, державне управління, захист державної безпеки, реформування правоохоронних органів, правоохоронна діяльність, організована злочинність, кримінальний аналіз ризиків, засади державної безпекової політики.

\section{НАПРАВЛЕНИЯ УСОВЕРШЕНСТВОВАНИЯ ЗАКОНОДАТЕЛЬНОГО ОБЕСПЕЧЕНИЯ МЕРОПРЯТИЙ В СФЕРЕ ЗАЩИТЫ ГОСУДАРСТВЕННОЙ БЕЗОПАСНОСТИ ПО ВЕКТОРУ - БОРЬБА С ОРГАНИЗОВАННОЙ ПРЕСТУПНОСТЬЮ}

Аннотация. Рассмотрены проблемные вопросы реализации государственной политики Украины в сфере борьбы с организованной преступностью как стратегического вектора обеспечения государственной безопасности. 
Осуществлен обзор законодательных инициатив и практических мероприятий, которые внедряются с целью построения концептов государственной политики в сфере борьбы с организованной преступностью в условиях реформирования правоохранительных органов. Определены содержание и направления стратегии борьбы с организованной преступностью как фундаментального документа, посвященного внедрению международных стандартов и формированию адекватной системы мероприятий касаемо недопущения и борьбы с деятельностью организованных преступных группировок, в том числе и с транснациональными связями. Проанализированы основы государственной политики безопасности, которые осуществляются с целью формирования институционного обеспечения борьбы с организованной преступностью. Детализированы перспективные направления усиления возможностей правоохранительных органов - субъектов борьбы с организованной преступностью, к которым относятся: практическое внедрение в их деятельность системы уголовного анализа и анализа рисков организованной преступности, совместимой со стандартами ЕС, в том числе, методологии оценки угроз организованной преступности и тяжелых преступлений (SOCTA Украина); налаживание сотрудничества с Интерполом, Европолом и другими международными партерами на двусторонней и многосторонней основе в соответствие с национальным законодательством и ратифицированными договорами. Обобщены направления повышения эффективности правоохранительной деятельности в сфере борьбы с организованной преступностью в контексте обеспечения государственной безопасности Украины, механизмы налаживания стратегических коммуникаций в сфере борьбы с организованной преступностью. Акцентировано внимание на необходимости усиления управленческой деятельности Правительства Украины касаемо разработки и утверждения плана мероприятий во исполнение стратегии борьбы с организованной преступностью, подготовки рекомендаций по результатам анализа внедренных концептов государственной политики в сфере борьбы с организованной преступностью. Определена целесообразность проведения оценки состояния исполнения стратегии борьбы с организованной преступностью с использованием критериев, исходя из лучших правоохранительных практик европейского опыта. Обоснована необходимость обнародования на национальном уровне ежегодного отчета по реализации государственной политики в сфере борьбы с организованной преступностью. Определены приоритетные задачи современной правоохранительной деятельности и направления усовершенствования законодательного обеспечения в сфере защиты государственной безопасности.

Ключевые слова: государственная политика в сфере борьбы с организованной преступностью, государственное управление, защита государственной безопасности, реформирование правоохранительных органов, правоохранительная деятельность, организованная преступность, уголовный анализ рисков, основы государственной политики безопасности. 
Problem statement. Ukraine continues to reform the law enforcement system aimed at building an effective integrated mechanism to overcome the prerequisites and causes of the spread of organized crime, based on the best European practices in order to introduce modern criminal analysis systems, in particular the Europol "SOCTA" methodology, into the practical plane of Ukrainian realities. The establishment of an effective system of combating crime, in particular organized crime, remains an indispensable condition for the political and economic development of the state, as well as Ukraine's compliance with international obligations under the concepts of the UN and the Council of Europe in the field of combating crime.

So, the systematic nature of a consistent and balanced state policy in the fight against organized crime should be declared in the fundamental strategic documents of the national level. At the same time, legislative changes, institutional and other changes, including effective coordination between the relevant authorities, enshrined in the Concept of state policy in the fight against organized crime, approved by the Decree of the President as of Ukraine of October 21, 2011 № 1000 [1], which were designed for the period up to 2017, remained unfulfilled. In other words, it is possible to talk about the obsolescence of certain provisions of legislative and other regulatory acts, the existence of gaps in the organization of combating the activities of organized criminal groups, the lack of proper interaction and coordination of law enforcement agencies, the imperfection of the mechanism for monitoring the criminal situation and its assessment and, as a result, about the low effectiveness of the results of the fight against organized crime. In particular, the first report of the European Commission under the new mechanism of temporary suspension of visa-free regimes with third countries dated as of December 20, 2017, which proclaimed recommendations to strengthen the government's efforts to counter organized crime, speaks about the urgency of the state policy of Ukraine in the fight against organized crime.

The Action Plan for the liberalization of the visa regime for Ukraine provided for the approval of a comprehensive strategy to combat organized crime, along with an Action Plan that has time frames, specific goals and activities, performance indicators, sufficient resources (paragraph 2.3.1). On the basis of the foregoing, the effective implementation of international obligations and the relevant provisions of the National Security Strategy of Ukraine and the Security and Defense Sector Development Concept, approved in accordance with the Decrees of the President of Ukraine dated as of May 26, 2015 № 287/2015 [2] and March 14, 2016 № 92/2016 [3], requires preparing a new strategy of combating organized crime, which provided for the introduction of a complex of adequate and weighted organizational and legal measures and law enforcement actions, taking into account the stages of reform and the formation of new law enforcement agencies. Such a strategy should include a wide range of issues related to the spread of this negative phenomenon, and determine the complex ways of building a systemic resistance to organized crime. 
Analysis of recent publications and researches. The problems of searching and optimizing the priority principles of state policy in the field of combating organized crime and identifying ways to improve the legal framework for coordination and interaction in the fight against organized crime in a certain way were explored by the following scientists in their works: Kolesnyk V. T. [4], Lytvynenko V. I. [5], Shepetko S. A. [6], Fedosova O. V., Mykhailova Yu. O. [7] and others. However, consideration of the strategic basis for legislative support of state policy in the fight against organized crime under the conditions of reforming law enforcement agencies, none of these authors did, which reinforces the relevance of the topic of this study.

Formulation of the aim of the article. The aim of the article is to determine the directions of improvement legislative measures in the sphere of state security in the fight against organized crime.

Presentation of the main material of the study. In recent years in Ukraine, certain documents of a strategic departmental nature have been approved and are in effect, the provisions of which declare state policy priorities in certain specific areas of law enforcement. In particular, on November 23, 2015, the Cabinet of Ministers of Ukraine approved the Development Strategy of the State Border Service of Ukraine [8]; on November 15, 2017, at the government level, the authorities approved the development strategy of the system of the Ministry of Internal Affairs for the period until 2020 [9]. However, efforts to adopt an integrated strategy to combat organized crime with the partici- pation of responsible entities, namely, law enforcement agencies have not yet yielded the expected positive result.

It is well known that the strategy to combat organized crime is a comprehensive fundamental document that defines the directions and mechanisms for implementing state policy to improve legislative and institutional support, ways to establish effective interaction and coordination, as well as enhance international cooperation in the fight against organized crime in modern conditions. The purpose of this program document is to identify ways to ensure the effective fight against organized crime through the introduction of international standards and the formation of an adequate system of measures to prevent and combat the activities of organized crime groups, primarily in the economic and financial-banking sectors and cyberspace. Thus, for the state, the Strategy for Combating Organized Crime is an essential act, which should determine important organizational and legal directions and address pressing issues of countering organized crime at the strategic and tactical levels. The draft Strategy was to be prepared in accordance with the National Security Strategy of Ukraine and the commitments made by Ukraine as part of the Association Agreement between Ukraine and the EU, the Action Plan for its implementation, to protect the rights and freedoms of man and citizen, the interests of the private sector, society and state from threats of organized crime.

It should be pointed out that it is the Strategy for the Fight against Organized Crime that should become a fundamental document, the provisions 
of which should determine the directions for the further development of the system for combating organized crime and the mechanisms for implementing state policy in this field. This document acquires particular relevance in the context of armed aggression against Ukraine, large-scale manifestations of separatism, efforts and attempts to form terrorist organizations, in connection with which organized crime is a direct and immediate threat to the national security of Ukraine. Escalation of cruelty and violence, destabilization of the internal socio-political situation leads to disruption of the functioning of state and local government bodies, as well as undermining the authority of the state and its bodies among the population.

Therefore, the principles of the state policy in the fight against organized crime should also be reflected in the Strategy, which should include: the definition of an approach based on information obtained as a result of practical measures to combat organized crime; identification of risks and threats posed by organized criminal activity, their constant analysis and response to them; the implementation by state bodies, civil society institutions and foreign partners of targeted, forwardlooking, concerted and complementary measures in the fight against organized crime; ensuring an integrated, methodical and holistic approach to combating organized crime, including taking measures to prevent and suppress the activities of organized criminal groups, both strategic nature (that are trying to influence the threat) and operational one (that are trying to influence specific organized criminal groups and their participants).
The abovementioned indicates the relevance and expediency of preparing a new fundamental document that would proclaim at the national level the principles of state policy in the fight against organized crime. Unfortunately, at the end of 2018, our State did not have a basic strategic document that would determine state policy priorities aimed at overcoming the causes and factors of organized crime in Ukraine and its prerequisites.

It is worth noting that the decision of the Council of National Security and Defense of Ukraine "On urgent measures to neutralize threats to national security in the field of migration policy", enacted by Decree of the President of Ukraine as of March 17, 2018 № 72/2018 [10], is declared by regulatory standards that until July 1, 2018, the Cabinet of Ministers of Ukraine should develop and approve a draft Strategy for Combating Organized Crime together with an action plan that will contain specific goals, activities, deadlines, expected results, performance indicators sufficiently resourced, providing a comprehensive introduction of modern systems of criminal analysis, in particular Europol methodology. To implement this decision, in accordance with the letter of the Secretary of the National Security and Defense Council of Ukraine, A. Turchinov, as of dated February 8, 2017 № 204/11-05/2-18, the Cabinet of Ministers of Ukraine instructed all responsible entities, including the Ministry of Internal Affairs, the Security Service of Ukraine, the National Anti-corruption Bureau of Ukraine, the State Financial Monitoring Service, Ministry of Economic Development and Trade, Ministry of Justice, National 
Police, State Border Guard Service of Ukraine, State Fiscal Service, National Agency on Corruption Prevention, Asset Recovery and Management Agency to join efforts to develop a Strategy, the draft of which was expected to be submitted to the Government before July 1, 2018. An interdepartmental working group was established to fulfill the order of the Cabinet of Ministers and the National Security and Defense Council of Ukraine, which was approved by the Order of the Ministry of Internal Affairs of Ukraine as of 03.05.2018 № 361, with the aim of a collegial interdepartmental discussion of the draft Strategy for Combating Organized Crime and its Action Plan implementation prepared jointly by the Ministry of Internal Affairs of Ukraine and European colleagues, which were subsequently sent to the authorized state and law enforcement agencies with a view to their harmonization. However, unfortunately, even at the beginning of 2019, neither the Strategy nor the Action Plan for its implementation were finalized by the Government.

In the framework of the implementation of the provisions of the Strategy at the national level, the problems of combating organized crime are planned to be solved by: improving the regulatory framework for combating organized crime; creating an effective system of institutional support for combating organized crime; involving the public to actively participate in the fight against organized crime; intensifying and strengthening international cooperation in the fight against organized crime; information, analytical, scientific and personnel support for the fight against organized crime.
One of the important areas should be determined by strengthening the capabilities of law enforcement agencies the subjects of the fight against organized crime, which is impossible without introducing a system of criminal analysis and risk analysis of organized crime into their activities, which comply with the EU standard, provides for the development and implementation of a standardized analytical methodology for assessing the threat of organized crime and serious crimes (SOCTA Ukraine), its use to assess the real situation in this area and identify gaps in STEM to obtain relevant operational information. Thus, the priority should be effective cooperation with Interpol, Europol and other international partners on a bilateral and multilateral basis in accordance with national legislation and international treaties, the creation and development of a national police database associated with international databases.

As rightly pointed out by V. A. Hlukhoveria, for Ukraine, which has chosen a course for European integration, it is very important to study and use the positive experience of reforming law enforcement agencies in Western states. The reforms initiated recently in law enforcement, along with improving the functioning of the law enforcement system, should help increase public confidence in the latter, establish justice, legitimacy, and serve as additional guarantees for ensuring the rights of citizens. At the same time, in his opinion, the main lack of reforms in the domestic law enforcement sphere is the lack of a consistent state policy, which should be based on the principles of planning and consistency [11]. 
Considering the above, the effectiveness of law enforcement in the fight against organized crime should include the introduction of active forms of cooperation with similar structures of foreign states through the exchange of information about criminal organizations and individuals involved in their activities; organizing and conducting joint operational activities and cross-border operations to prevent and counter organized crime, including the expansion of the exchange of experience, internships and joint training of specialists of special units to combat organized crime, the introduction of international technical assistance projects aimed at strengthening the capabilities of bodies engaged in the fight against organized crime, the supply of modern special equipment, weapons and other means of combating organized crime.

The provisions of the Strategy should regulate the procedure for the use by state bodies involved in combating organized crime of the latest methods of risk management, threat assessment and the impact of cross-border and transnational organized crime on sociopolitical and socio-economic processes in the state in order to take preventive measures for their localization and minimization of possible negative consequences. Against this background, it is also advisable to ensure the harmonization of statistical reporting forms of law enforcement agencies on recording criminal offenses related to organized criminal activity with statistical reporting forms of the judiciary based on the results of criminal proceedings on such offenses reviewed by courts, to declaratively define the authorized body to prepare the annual report on the imple- mentation of public policy in the fight against organized crime and special status reports on organized crime in Ukraine, the main directions and results of the fight against such crime, as well as resource needs.

E. Skulysh rightly points out that the criminal policy of the state should be offensive in nature and be implemented in a regime of tighter opposition to crime $[12$, p. 128]. To conclude, it is impossible to improve the state of the criminogenic situation without improving the mechanism of research support for combating organized crime, while providing for a systematic and comprehensive study of the existing problems of regulatory and institutional support for combating organized criminal groups based on the best practices of foreign experience.

The basic provisions of the Strategy should also reflect the mechanisms for establishing strategic communications in the fight against organized crime: the creation of strategic narratives aimed at supporting society in the actions of bodies engaged in the fight against organized crime; active involvement of civil society institutions; the declared rejection of the practice of tolerance by the government and the society of actions of organized crime. Of course, the implementation of the provisions of the Strategy should be carried out consistently on the basis of optimal and balanced decisions, which should take into account the positive experience and best practices of the leading EU states. As M. Kryshtanovych objectively notes, according to the European experience, law enforcement activities should be carried out in such a way that their main focus is on the immediate and long-term 
service of the population in the field of enhancing its security [13].

Also, in order to implement the Strategy, an appropriate Action Plan should be developed and approved by the Government of the State, which should be subject to an imperative order of annual review, taking into account the results of the implementation of certain measures, conclusions and recommendations of the annual report on the implementation of state policy in the fight against organized crime. The plan of measures for the implementation of the Strategy should include specific measures, deadlines for their implementation, a list of responsible executors and expected results (performance indicators). The practical implementation of the provisions of the Strategy will significantly reduce the spread of organized crime in Ukraine, increase public confidence in the authorities, and create the necessary conditions for the growth of foreign investment in the state's economy.

An important aspect of law enforcement activity in the field of combating organized crime remains the assessment of the implementation status of the Strategy, which should be based on the implementation of the Action Plan for its implementation, which is included in the annual report on the implementation of state policy in the fight against organized crime. Criteria for such an assessment should be the following points: the creation of an adequate system of measures to prevent and combat organized crime in the economic, financial and banking sectors and cyberspace; the introduction of international standards in these fields and effective mechanisms for coordination and interaction; in- creasing the effectiveness of the bodies engaged in the fight against organized crime, and the deepening of their international cooperation.

Conclusions and prospects for further research. The deterioration of problems related to organized crime, first of all, is a consequence of the imbalance of regulatory support and the lack of a strategic systems approach at the national level in the organization to counter this phenomenon. Given the complex nature of organized crime, the deterioration of the crime situation, the organization of a systemic fight against organized crime should be one of the priority tasks of modern state security. Given the complex nature of organized crime, the deterioration of the crime situation, the organization of a systemic fight against organized crime should be one of the priority tasks of modern state security. Unfortunately, the government's activity in this direction is rather slow, irresponsible and worthless. Since before July 1, 2018, the Cabinet of Ministers of Ukraine had to develop and approve a draft Strategy for Combating Organized Crime together with an Action Plan for its implementation, one of the key tasks of the Government of Ukraine remains the immediate formation and regulatory consolidation of the basis of state policy in the fight against organized crime. This, in turn, provides for the acceleration of the adoption of a modern strategy to combat organized crime as a fundamental document that declares and identifies priority areas and mechanisms for implementing state policy to improve legislative and institutional support, establish effective interaction and coordination within the domestic law enforcement system, 
enhance transnational cooperation in the fight against organized crime in the modern conditions.

Also it is advisable to introduce the European experience in order to strengthen the political responsibility of the government, in particular its authorized officials of the Department of security, defense, the activities of justice and corruption prevention of the Cabinet of Ministers of Ukraine, responsible for supporting the development and approval of nation-wide strategic documents on government level, implementation of state security. Prospective scientific studies on this issue have to cover the stages of regulatory support for the further implementation of the priorities of the Organized Crime Strategy, taking into account the existing positive European experience, practical implementation of modern criminal analysis systems, in particular, the methodology of the European Police Office, strengthening of interdepartmental interaction, monitoring the implementation of the plan of measures for its implementation by the responsible entities, which is subject to annual refinement taking into account the achievements, conclusions and recommendations of the annual assessment of the state of the implementation of state control policy with organized crime.

\section{REFERENCES}

1. Ukaz Prezydenta Ukrainy Pro Kontseptsiiu derzhavnoi polityky u sferi borotby $\mathrm{z}$ orhanizovanoiu zlochynnistiu vid 21 zhovtnia 2011 roku \# 1000 [Decree of the President of Ukraine On the concept of state policy in the field of fighting organized crime as of October 21, 2011 № 1000]. Retrieved from http://zakon.rada.gov.ua/laws/ show/1000/2011 [in Ukrainian].

2. Ukaz Prezydenta Ukrainy Pro rishennia Rady natsionalnoi bezpeky i oborony Ukrainy vid 6 travnia 2015 roku: Pro Stratehiiu natsionalnoi bezpeky Ukrainy vid 26 travnia 2015 roku \# 287/2015. [Decree of the President of Ukraine On the decision of the National Security and Defense Council of Ukraine as of May 6, 2015: On the Strategy of National Security of Ukraine as of May 26, 2015, № 287/2015]. Retrieved from https://zakon.rada.gov.ua/laws/ show $/ 287 / 2015$ [in Ukrainian].

3. Ukaz Prezydenta Ukrainy Pro rishennia Rady natsionalnoi bezpeky i oborony Ukrainy vid 4 bereznia 2016 roku: Pro Kontseptsiiu rozvytku sektoru bezpeky i oborony Ukrainy (vvedeno v diiu 14 bereznia 2016 roku \# 92/2016). [Decree of the President of Ukraine: On the Concept for the Development of the Security and Defense Sector of Ukraine as of March 04, 2016 (which was enacted by the as of March 14, 2016 № 92/2016)]. Retrieved from https://zakon.rada.gov.ua/laws/ show/92/2016 [in Ukrainian].

4. Kolesnyk V. T. (2015). Rozvytok ta udoskonalennia orhanizatsiino-pravovykh mekhanizmiv derzhavnoho upravlinnia u sferi zabezpechennia natsionalnoi bezpeky [Development and improvement of organizational and legal mechanisms of state administration in the field of ensuring national security]. Derzhavne upravlinnia: udoskonalennia ta rozvytok. - Public Administration: Improvement and Development, 12. Retrieved from http://www. dy.nayka.com.ua/?op $=1 \& z=1006 \quad$ [in Ukrainian].

5. Lytvynenko V. I. (2017). Kontseptualni zasady reformuvannia pravookhoronnykh orhaniv Ukrainy [Conceptual Principles of Reforming the 
Law Enforcement Bodies of Ukraine]. Naukovi pratsi MAUP. Seriia: Yurydychni nauky. - Scientific works of MAUP. Series: Law Sciences, issue 1, 7-16.Retrieved from http://nbuv.gov. ua/UJRN/Npmaupun_2017_1_4 [in Ukrainian].

6. Shepetko S. A., Klymenko O. A. (2017). Napriamy udoskonalennia normatyvno-pravovoho rehuliuvannia zabezpechennia koordynatsii ta vzaiemodii u sferi borotby z orhanizovanoiu zlochynnistiu [Directions for improving the regulatory framework to ensure coordination and interaction in the fight against organized crime]. Pytannia borotby zi zlochynnistiu. Issues of combating crime, issue 34, 15-27. Retrieved from http://nbuv. gov.ua/UJRN/Pbzz_2017_34_4 [in Ukrainian].

7. Fedosova O. V., Mykhailova Yu. O. (2016). Shliakhy vdoskonalennia derzhavnoi polityky u sferi borotby z orhanizovanoiu zlochynnistiu [Ways to improve state policy in the field of combating organized crime]. Naukovyi visnyk publichnoho ta pryvatnoho prava. - Scientific Bulletin of Public and Private Law, issue 6, Vol. 2, 190-195. [in Ukrainian].

8. Rozporiadzhennia Kabinetu Ministriv Ukrainy vid 23 lystopada 2015 roku \#1189: Pro skhvalennia Stratehii rozvytku Derzhavnoi prykordonnoi sluzhby Ukrainy [Order of the Cabinet of Ministers of Ukraine as of November 23, 2015, № 1189: On Approval of the Development Strategy of the State Border Guard Service of Ukraine]. Retrieved from https:// www.kmu.gov.ua/ua/npas/248650837 [in Ukrainian].

9. Rozporiadzhennia Kabinetu Ministriv Ukrainy vid 15 lystopada 2017 roku \#1023: Pro skhvalennia Stratehii rozvytku orhaniv systemy Ministerstva vnutrishnikh sprav na period do 2020 roku. [Order of the Cabinet of Ministers of Ukraine as of November 15, 2017, № 1023: On approval of the Development Strategy of the Ministry of Internal Affairs system for the period up to 2020]. Retrieved from https://zakon.rada.gov.ua/laws/ show $/ 1023-2017-\%$ D1\%80?lang=en [in Ukrainian].

10. Rishennia Rady natsionalnoi bezpeky i oborony Ukrainy Pro nevidkladni zakhody z neitralizatsii zahroz natsionalnii bezpetsi u sferi mihratsiinoi polityky vid 1 bereznia 2018 roku, vvedene v diiu Ukazom Prezydenta Ukrainy vid 17 bereznia 2018 roku \#72. [The decision of the National Security and Defense Council of Ukraine as of March 1, 2018 On urgent measures to neutralize threats to national security in the field of migration policy, which is enacted by Decree of the President of Ukraine as of March 17, 2018, № 72]. Retrieved from https://zakon.rada. gov.ua/laws/show/n0005525-18 [in Ukrainian].

11. Hlukhoveria V. A. (2016). MVS Ukrainy yak skladova reformuvannia sektoru bezpeky i oborony [Ministry of Internal Affairs of Ukraine as a component of the reform of the security and defense sector]. Forum prava. Law forum, 4. 72-76. Retrieved from http://nbuv.gov.ua/j-pdf/FP_index.htm_2016_4_14.pdf [in Ukrainian].

12. Skulysh Ye. D. (2003). Zahalnoderzhavna systema protydii orhanizovanii zlochynnosti: problemy formuvannia ta funktsionuvannia [National system of counteraction to organized crime: problems of formation and functioning]. Visnyk Khmelnytskoho instytutu rehionalnoho upravlinnia ta prava: Naukovyi chasopys. - Bulletin of the Khmelnitsky Institute of Regional Management and Law: Scientific Journal, 2 (6) 125-129. [in Ukrainian]. 
13. Kryshtanovych M. F. (2015). Yevropeiskyi dosvid derzhavnoho upravlinnia orhanamy politsii ta mozhlyvosti yoho vykorystannia v Ukraini [European experience of the state administration of the police authorities and the possibilities of its use in Ukraine]. Aktualni problemy derzhavnoho upravlinnia. - Actual problems of public administration, 1, 287293. Retrieved from http://nbuv. gov.ua/UJRN/apdy_2015_1_42 [in Ukrainian].

\section{СПИСОК ВИКОРИСТАНИХ ДЖЕРЕЛ}

1. Про Концепцію державної політики у сфері боротьби з організованою злочинністю: Указ Президента України від 21 жовтня 2011 р. № 1000 [Електронний ресурс]. Режим доступу: http://zakon.rada. gov.ua/laws/show/1000/2011

2. Про рішення Ради національної безпеки і оборони України від 6 травня 2015 р. "Про Стратегію національної безпеки України": Указ Президента України від 26 травня 2015 р. № 287/2015 [Електронний ресурс]. Режим доступу: https://zakon.rada. gov.ua/laws/show/287/2015

3. Про рішення Ради національної безпеки і оборони України від 4 березня 2016 р. "Про Концепцію розвитку сектору безпеки і оборони України”. Введено в дію Указом Президента України від 14 березня 2016 р. № 92/2016.

4. Колесник В. Т. Розвиток та удосконалення організаційно-правових механізмів державного управління у сфері забезпечення національної безпеки [Електронний ресурс] / В. Т. Колесник // Держ. управління: удосконалення та розвиток. 2015. № 12. Режим доступу: http://www. dy.nayka.com.ua/?op=1\&z=1006
5. Литвиненко В. I. Концептуальні засади реформування правоохоронних органів України [Електронний ресурс] / В. І. Литвиненко // Наук. пр. МАУП. Серія : Юрид. науки. 2017. Вип. 1. С. 7-16. Режим доступу: http://nbuv.gov.ua/UJRN/ Npmaupun_2017_1_4

6. Шепетько $C$. A. НАапрями удосконалення нормативно-правового регулювання забезпечення координації та взаємодії у сфері боротьби з організованою злочинністю / С. А. Шепетько, О. А. Клименко // Питання боротьби зі злочинністю. 2017. Вип. 34. С. 15-27.

7. Федосова О. В. Шляхи вдосконалення державної політики у сфері боротьби 3 організованою злочинністю / О. В. Федосова, Ю. О. Михайлова // Наук. вісн. публічного та приватного права. 2016. Вип. 6, т. 2. C. 190-195.

8. Про схвалення Стратегії розвитку Державної прикордонної служби України: розпорядження Кабінету Міністрів України від 23 листопада 2015 р. № 1189 [Електронний ресурс]. Режим доступу: https://www.kmu.gov.ua/ua/ npas $/ 248650837$

9. Про схвалення Стратегії розвитку органів системи Міністерства внутрішніх справ на період до 2020 року: розпоряження Кабінету Міністрів України від 15 листопада 2017 р. № 1023 [Електронний ресурс]. Режим доступу: https://zakon. rada.gov.ua/laws/show/1023-2017$\% \mathrm{D} 1 \% 80$ ?lang=en

10. Про невідкладні заходи з нейтралізації загроз національній безпеці у сфері міграційної політики: рішення Ради національної безпеки і оборони України від 1 березня 2018 р., введене в дію Указом Президента України від 17 березня 2018 р. № 72 [Електронний ресурс]. Режим до- 
ступу: https://zakon.rada.gov.ua/ laws/show/n0005525-18

11. Глуховеря В. А. МВС України як складова реформування сектору безпеки i оборони [Електронний ресурс] / В. А. Глуховеря // Форум права. 2016. № 4. С. 72-76. Режим доступу: http://nbuv.gov.ua/j-pdf/ FP_index.htm_2016_4_14.pdf

12. Скулиш Є. Д. Загальнодержавна система протидії організованій злочинності: проблеми формування та функціонування / Є. Д. Скулиш // Вісн. Хмельницького ін-ту регіо- нального управління та права: Наук. часопис. 2003. № 2 (6) / Хмельницький ін-т регіон. управління та права. C. 125-129.

13. Криштанович М. Ф. Європейський досвід державного управління органами поліції та можливості його використання в Україні [Електронний ресурс] / М. Ф. Криштанович // Актуальні проблеми державного управління. 2015. № 1. C. 287-293. Режим доступу: http:// nbuv.gov.ua/UJRN/apdy_2015_1_ 42 